\title{
O fluxo migratório guatemalteco para os Estados Unidos
}

João Pedro Censi Morlin Seelig Portela

\begin{abstract}
RESENHA: LA JAULA de Oro. Direção: Diego QuemadaDiez. Roteiro: Diego Quemada-Diez, Lucía Carreras e Gibrán Portela. Elenco: Brandon López, Rodolfo Dominguez e Karen Martínez. México, Espanha e Guatemala: Animal de Luz Films, Castafioris Films e Consejo Nacional para la Cultura y las Artes, 2013. DVD (108 min), son., color.
\end{abstract}

Com os movimentos de antiglobalização, os processos migratórios estão recebendo maior atenção por consequência do endurecimento das políticas migratórias dos países considerados fornecedores de oportunidades. Em contrapartida, populações de países periféricos fogem, para escapar das desigualdades sociais e econômicas ocasionadas por fatores externos, como manutenção de poder e zona de influência de países centrais, ou por fatores internos, como guerras-civis e ditaduras. Neste contexto, encontram-se os países centro-americanos, em especial, a Guatemala, objeto desta resenha e do filme La Jaula de Oro.

Mesmo tratando-se de uma ficção, o filme dirigido por Diego Quemada-Díez chama a atenção pela cinematografia que explora as vegetações guatemaltecas e mexicanas, mas também por alertar para os novos fluxos migratórios de jovens e crianças guatemaltecos que buscam chegar aos Estados Unidos para conquistar uma vida melhor e novas oportunidades. O filme apresenta a trajetória de dois jovens guatemaltecos (Sara e Juan) e um indígena do povo Tsotsi (Chauk) que buscam chegar aos Estados Unidos, atravessando o México, agrupados em cima de trens de carga

\section{$\overline{\text { João Pedro Censi Morlin Seelig Portela }}$}

Graduando do curso de Relações Internacionais da Escola Superior de Marketing e Propaganda (ESPM-Sul). Bolsista do Programa de Iniciação Científica fomentado pela mesma instituição (PIC/ESPM) na área de Segurança Internacional e Defesa. E-mail: jpedromorlinportela@gmail.com. 
que cruzam a fronteira México-Guatemala até a fronteira MéxicoEstados Unidos.

Ao longo do caminho pelo México, são retratadas diversas situações que os imigrantes podem sofrer ao cruzar fronteiras de forma irregular, como tráfico humano e abordagem de cartéis e gangues. O "trem da morte", como é conhecido o percurso fora da ficção, apresenta os riscos de ataques por agentes não estatais, o que é muito temido pelos imigrantes que se agrupam em cima do trem, e os riscos da atuação dos agentes de migração mexicana, haja visto que os migrantes poderão ser deportados a seus países originários.

La Jaula de Oro, além de trazer à luz novas informações sobre o caminho percorrido pelos imigrantes guatemaltecas e a intensificação de jovens nos fluxos migratórios, também introduz o papel do México, não como um país expoente das migrações para os Estados Unidos, mas como corredor para o imigrante centro-americano que busca uma vida nova no território mexicano ou estadunidense. Este fenômeno pode ser observado em uma caravana centro-americana formada em outubro de 2018, que visava chegar aos Estados Unidos, mas na qual havia imigrantes que se estabeleceram no México.

O filme guatemalteco de 2013 ilustra o comportamento dos fluxos migratórios centro-americanos que permeiam a região e as ações dos Estados, diante dessas movimentações espontâneas. Sendo assim, o filme possibilita refletir sobre as políticas migratórias do México, executadas em consonância com o governo Obama II, e as novas políticas do presidente López Obrador, que, para evitar conflitos com os Estados Unidos, atua em conjunto ao presidente Trump.

O temor que os imigrantes centro-americanos têm pelos agentes estatais presentes na fronteira México-Estados Unidos é semelhante ao de quando se trata da fronteira Guatemala-México. A deportação é uma prática que contraria recomendações internacionais, uma vez que o imigrante que fugiu da violência e/ou pobreza do seu país é colocado novamente em risco. Em 2016, o Estado mexicano realizou pouco mais de 132 mil deportações de imigrantes do Triângulo Norte da América Central (NTCA em 
inglês) ${ }^{1}$ (OROZCO, 2018), enquanto os Estados Unidos realizaram mais de 76 mil deportações, no mesmo período.

Além do desrespeito ao princípio de non-refoulement, outras ações das políticas ostensivas contra imigrantes também infringem os direitos humanos. Esse é o caso das separações familiares durante os processos de deportação, em particular quando crianças são separadas dos pais que recebiam processos criminais ao violar o Ato de Imigração e Nacionalidade de 1952. Como as crianças não respondiam juridicamente, eram separadas dos pais e enviadas a abrigos, até terminar a busca por um parente próximo residente nos Estados Unidos. Esse procedimento foi denunciado em junho de 2018 e recebeu destaque e conhecimento internacional, mas, mesmo após o decreto que colocou fim à política de "tolerância zero", ainda ocorrem denúncias de que as separações continuam acontecendo.

Embora adote políticas austeras no que tange à migração, Obrador tenta uma parceria com Trump em que pretende criar políticas econômicas de desenvolvimento dos países do NTCA. Essa estratégia pertence à mesma linha da ajuda econômica que os Estados Unidos já oferece, porém com mais recursos, objetivando diminuir as migrações por meio da geração de emprego e da reforma institucional dos países. Além da ajuda econômica, o México estudaria a possibilidade de flexibilizar suas leis migracionais.

A austeridade que o governo estadunidense está adotando em relação às decorrentes migrações centro-americanas não tem surtido efeito positivo. O corte de ajuda econômica que o presidente Trump ameaça fazer tem como consequência o aumento gradual das migrações centro-americanas. Todavia, a proposta de López Obrador de ajuda econômica possibilita processos que visam desenvolver os países da América Central e, por conseguinte, a diminuição do número de imigrantes. Por muitos anos, os Estados Unidos optaram pelo controle ostensivo de suas fronteiras como método para diminuir o fluxo migratório de mexicanos; porém, o número de imigrantes mexicanos diminuiu com o desenvolvimento da fronteira e mudanças no controle migracional. $L a$

1 Esta nomenclatura refere-se a Guatemala, El Salvador e Honduras. 
Jaula de Oro trata com clareza do processo de migração centro-americana e os riscos que os imigrantes passam ao cruzar o México, estabelecendo uma analogia entre as travessias mexicanas para os Estados Unidos e as centro-americanas para os países do norte.

\section{REFERÊNCIAS}

OROZCO, Manuel. Recent trends in central American migration. The dialogue, Washington, 14 de maio de 2018. Disponível em: <https://www. thedialogue.org/analysis/recent-trends-in-central-american-migration/>. Acesso em: 05 mar. 2019. 